\section{Implementation of a smoke- free Psychiatric Unit in a general hospital}

\section{Implantação de Unidade Psiquiátrica livre de tabaco em um hospital geral}

\section{Dear Editor,}

Smoking is more prevalent among patients with severe mental disorders than in the general population. Moreover, other health threatening factors, such as obesity, sedentary lifestyle, and less attention to general health and self-care, contribute to increase the morbidity and early mortality in this population. ${ }^{1}$

The relationship between psychopathology and smoking (selfreported cognitive improvement, decrease in antipsychotic sideeffects, and anxiety), ${ }^{2}$ together with restrictions on the use of some medications and behavioral strategies, are some of the difficulties in the nicotine dependence treatment for these patients. Currently, nicotine replacement therapy (NRT) has been considered to be the most effective and safest option to aid smoking cessation in this population. ${ }^{3}$

The Hospital das Clinicas da Universidade Estadual de Campinas (HC-UNICAMP) has 3,100 employees and 394 beds. It is a reference institution in health care, teaching, and research, and therefore it has an exemplary role in providing high-standard care and environment. Its 12-bed Psychiatric Unit (PU) admits patients suffering from mood disorders (34\%), psychotic disorders and schizophrenia (28\%), personality disorders $(12 \%)$, organic mental disorders $(9 \%)$, and disorders related to the use of psychoactive substances $(7 \%) .^{4}$

In the beginning of 2008, a multisectoral committee was created in order to implement measures to make the hospital 100\% free from tobacco. One of the main obstacles to achieve that goal was the fact that the fourth floor of the building, where the PU is located, used to be regarded by both patients and professionals as a smoking area. Table 1 describes the main measures taken to ban smoking in the hospital.

Between June 2008 and May 2009, 196 patients were hospitalized at the PU, $26 \%$ of whom were smokers. On average, they were 37 years old and had been smoking 22 cigarettes per day for the last 19 years. Twelve months after hospital discharge, all patients were contacted by telephone and interviewed: $31 \%$ maintained the same smoking pattern, $27 \%$ reduced the number of cigarettes smoked per day, 10\% had quit smoking but relapsed, and $27 \%$ had quit smoking completely since the time they were hospitalized.

The two main difficulties identified in the smoke-free program were the resistance of hospital employees to acknowledge that the fourth floor was no longer a place for smoking, and the lack of NRT for all the hospital wards. Overall, the implementation of the program was smoother than initially expected. There were neither increased reports of aggressive behavior nor admission refusals. The old "negotiations" between staff and patients, who used cigarettes as an exchange currency, have been replaced by walking at the hospital yard, dominoes matches, and listening to the piano available on the fourth floor. Some hospital professionals also stopped smoking.

The comment made by an interviewed patient reinforces the importance of the initiative and encourages other services to do the same: "I thought it's all right [not being allowed to smoke in

Table 1 - Strategies used to implement the $100 \%$ tobacco-free program

\begin{tabular}{|c|c|c|}
\hline Activities & Objectives & Results \\
\hline \multicolumn{3}{|l|}{ At the hospital } \\
\hline Campaign launched in May 2008 & $\begin{array}{l}\text { "No Tobacco Day" used as a trigger for } \\
\text { subsequent activities }\end{array}$ & $\begin{array}{l}\text { Formalization of hospital commitment/The media } \\
\text { spread the news and contributed to the campaign }\end{array}$ \\
\hline $\begin{array}{l}\text { Smoking prevalence surveyed among } \\
\text { hospital employees }\end{array}$ & $\begin{array}{l}\text { To get user profile and prevalence rate in } \\
\text { a random sample of } 628 \text { individuals }\end{array}$ & $\begin{array}{l}19 \% \text { smokers (women: } 18 \% \text { and men: } 23 \% \text { ), } 72 \% \\
\text { had tried to quit smoking, } 39 \% \text { wanted to quit right } \\
\text { away, and } 22 \% \text { within the following six months } / 74 \% \\
\text { reported will to receive help to stop smoking }\end{array}$ \\
\hline Workshops on smoking for staff & $\begin{array}{l}\text { Health-related (and not witch-hunt) } \\
\text { campaign/Treatment alternatives available }\end{array}$ & $\begin{array}{l}\text { Nine workshops were conducted in the morning, } \\
\text { afternoon, and night shifts }\end{array}$ \\
\hline Treatment support & $\begin{array}{l}\text { Information and access to treatment for } \\
\text { employees }\end{array}$ & $\begin{array}{l}\text { Dissemination of treatment services in the university } \\
\text { campus/Pharmacological treatment partially } \\
\text { subsidized }\end{array}$ \\
\hline \multicolumn{3}{|l|}{ At the Psychiatric Unit } \\
\hline Presentation of the program to staff & To deal with professionals' expectations & $\begin{array}{l}\text { Concerns on how to handle patients' "insistence" and } \\
\text { hostility/Cigarette smoking by staff members was } \\
\text { also questioned }\end{array}$ \\
\hline $\begin{array}{l}\text { Smoking prevalence surveyed among } \\
\text { patients admitted during } 30 \text { days }\end{array}$ & $\begin{array}{l}\text { To estimate the number of smokers and } \\
\text { the nicotine replacement therapy (NRT) } \\
\text { needed }\end{array}$ & $\begin{array}{l}35(26 \%) \text { smokers. Considering this rate and the } \\
\text { average stay ( } 22 \text { days), it was estimated that } 100 \\
\text { units of gum, } 4521 \mathrm{mg} \text { - and } 514 \mathrm{mg} \text {-nicotine patches } \\
\text { would be necessary }\end{array}$ \\
\hline $\begin{array}{l}\text { Motivational groups for patients and } \\
\text { guidance to relatives }\end{array}$ & $\begin{array}{l}\text { Awareness and focus on the prohibition of } \\
\text { cigarette use during hospitalization }\end{array}$ & $\begin{array}{l}\text { Performed by professionals from the PU and } \\
\text { smoking cessation outpatient clinic/Patients and their } \\
\text { relatives more receptive than expected }\end{array}$ \\
\hline Training for NRT use & $\begin{array}{l}\text { To train the staff, especially the psychiatric } \\
\text { residents, to prescribe NRT }\end{array}$ & $\begin{array}{l}35 \text { patients treated } / 1,252 \text { units of gum } / 55021 \mathrm{mg} \text { - } \\
\text { and } 5514 \mathrm{mg} \text {-nicotine patches were used }\end{array}$ \\
\hline
\end{tabular}


the hospital] because I started smoking inside a psychiatric hospital. At that time, I was admitted with one disease and discharged with two! For those admitted today, this no longer happens".

Renata Cruz Soares de Azevedo, José Luiz Risi Leme, Fabrício Zacche Miranda, Neury José Botega Department of Medical Psychology and Psychiatry, Faculdade de Ciências Médicas, Universidade Estadual de Campinas (UNICAMP), Campinas, SP, Brazil

Celina Matiko Hori Higa Psychiatric ambulatory, Hospital das Clínicas, Universidade Estadual de Campinas (UNICAMP), Campinas, SP, Brazil

Disclosures

\begin{tabular}{|c|c|c|c|c|c|c|c|}
\hline $\begin{array}{l}\text { Writing group } \\
\text { member }\end{array}$ & Employment & $\begin{array}{l}\text { Research } \\
\text { grant }^{1}\end{array}$ & $\begin{array}{c}\text { Other research grant or } \\
\text { medical continuous } \\
\text { education }\end{array}$ & $\begin{array}{l}\text { Speaker's } \\
\text { honoraria }\end{array}$ & $\begin{array}{l}\text { Ownership } \\
\text { interest }\end{array}$ & $\begin{array}{l}\text { Consultant/ } \\
\text { Advisory } \\
\text { board }\end{array}$ & Other ${ }^{3}$ \\
\hline $\begin{array}{l}\text { Renata Cruz } \\
\text { Soares de } \\
\text { Azevedo }\end{array}$ & $\begin{array}{c}\text { FCM- } \\
\text { UNICAMP }\end{array}$ & - & - & - & - & - & - \\
\hline $\begin{array}{l}\text { José Luiz Risi } \\
\text { Leme }\end{array}$ & $\begin{array}{c}\text { FCM- } \\
\text { UNICAMP }\end{array}$ & - & - & - & - & - & - \\
\hline $\begin{array}{l}\text { Fabrício Zacche } \\
\text { Miranda }\end{array}$ & $\begin{array}{c}\text { FCM- } \\
\text { UNICAMP }\end{array}$ & - & - & - & - & - & - \\
\hline $\begin{array}{l}\text { Neury José } \\
\text { Botega }\end{array}$ & $\begin{array}{c}\text { FCM- } \\
\text { UNICAMP }\end{array}$ & - & - & - & - & - & - \\
\hline $\begin{array}{l}\text { Celina Matiko } \\
\text { Hori Higa }\end{array}$ & UNICAMP & - & - & - & - & - & - \\
\hline \multicolumn{8}{|c|}{$\begin{array}{l}\text { *Modest } \\
\text { ** Significant } \\
\text { *** Significant: Amounts given to the author's institution or to a colleague for research in which the author has participation, not directly to the } \\
\text { author. } \\
\text { Note: FCM-UNICAMP = Faculdade de Ciências Médicas, UNICAMP = Universidade Estadual de Campinas. } \\
\text { For more information, see Instructions for authors. }\end{array}$} \\
\hline
\end{tabular}

References

1. Jochelson K. Smoke-free legislation and mental health units: the challenges ahead. Br J Psychiatry. 2006;89:479-80.

2. Hennekens CH, Hennekens AR, Hollar D, Casey DE. Schizophrenia and increased risks of cardiovascular disease. Am Heart J. 2005;150(6):1115-21.
3. Lawn S, Pols R. Smoking bans in psychiatric inpatient settings? A review of the research. Aust NZ J Psychiatry. 2005;39(10):866-85.

4. Dalgalarrondo P, Banzato CE, Botega NJ. Psychiatric admissions in a Brazilian general hospital: a review of outcomes. Gen Hosp Psychiatry. 2003;25(2):139-40. 